\title{
Meningkatkan Motivasi Belajar Pendidikan Agama Kristen Melalui Metode Belajar Kelompok Dan Tanya Jawab Kelas VII B SMP PGRI Salawati Kabupaten Sorong
}

\author{
Erika Sirait \\ SMP PGRI Salawati Kabupaten Sorong \\ Email : siraiterika@ymail.com
}

\begin{abstract}
The purpose of this research is to improve learning motivation of Christian education by the use of group learning and discussioon in the learning process of VII B grade VII SMP PGRI Salawati. This research use two cycles. The subject of this research were all student of VII B grade SMP PGRI Salawati which amounted 10 students of 4 male students and 6 female students. The method used is group discussion method question and answer method and lecture method. The result of the research showed that learning motivation to Christian education of VII B grade can improve. This is demonstrated by the increase in the average of score motivation at first cycle (70\%) to $100 \%$ in second cycle.

Keywords: group learning, discussion, learning motivation, Pendidikan Agama Kristen, SMP PGRI Salawati
\end{abstract}

Abstrak: Penelitian ini bertujuan untuk meningkatkan motivasi belajar Pendidikan Agama Kristen melalui penerapan belajar kelompok dan tanya jawab dalam proses pembelajaran pada siswa kelas VII B SMP PGRI Salawati Kabupaten Sorong. Penelitian ini dalam dua siklus. Subyek penelitian adalah seluruh siswa kelas VII B SMP PGRI Salawati Kabupaten Sorong yang berjumlah 10 siswa. Metode yang digunakan adalah metode diskusi kelompok, metode tanya jawab dan metode ceramah. Hasil penelitian menunjukkan bahwa motivasi belajar siswa terhadap mata pelajaran Pendidikan Agama Kristen siswa kelas VII B meningkat. Hal ini ditunjukkan oleh peningkatan rata-rata skor motivasi pada siklus I (70 \%) menjadi $100 \%$ pada siklus II.

Kata Kunci : Belajar kelompok, tanya jawab, motivasi belajar, Pendidikan Agama Kristen, SMP PGRI Salawati

\section{Pendahuluan}

Standar Kompetensi dan Kompetensi Dasar Pendidikan Agama Kristen bukanlah "standar moral" Kristen yang ditetapkan untuk mengikat peserta didik, melainkan dampingan dan bimbingan bagi peserta didik dalam melakukan perjumpaan dengan Tuhan Allah dan mengekspresikan hasil perjumpaan itu dalam kehidupan sehari-hari. Peserta didik belajar memahami, mengenal dan bergaul dengan Tuhan Allah secara akrab karena seungguhnya Tuhan Allah itu ada dan selalu ada dan berkarya dalam hidup mereka. Dia adalah Sahabat dalam Kehidupan Anak-anak.

Pendidikan agama merupakan rumpun mata pelajaran yang bersumber dari kitab suci setiap agama yang dapat mengembangkan kemampuan siswa dalam memperteguh iman dan takwa kepada Tuhan yang Maha Esa, serta berakhlak mulia atau budi pekerti luhur dan menghormati serta menghargai semua manusia dengan segala persamaan dan perbedaannya (Kemendikbud, $2013:$ 10). 
Berkaitan dengan upaya peningkatan mutu pendidikan di Indonesia, perlu dilakukan peningkatan pengajaran dan pembelajaran Pendidikan Agama Kristen oleh pengajar agar diperoleh peserta didik yang bermoral baik dan berkahlak mulia pada diri siswa sejak dini. Pelaksanaan pelajaran agama di sekolah selama ini sudah berjalan. Sekolah-sekolah di Indonesia memberlakukan/ memasukkan pelajaran agama dalam kurikulum.

Pembelajaran berkualitas dapat dicapai apabila guru mau melakukan penerapan strategi, model dan media pembelajaran. Maka dari itu peran guru diharapkan dapat menciptakan kondisi yang mendorong atau menumbuhkan semangat siswa untuk melakukan aktivitas belajar dengan baik memberi motivasi kepada siswa untuk belajar.

Penerapan belajar kelompok merupakan salah satu strategi belajar mengajar yang memiliki kadar cara belajar siswa aktif (Hasibuan dan Moedjiono, 2009:24). Penerapan kelompok belajar bertujuan untuk mengembangkan keterampilan-keterampilan untuk berperan dalam kelompok yang menekankan keterampilan komunikasi interpersonal dan keterampilan inkuari ilmiah. Selanjutnya, metode tanya jawab merupakan suatu metode yang bertujuan untuk menarik perhatian siswa agar lebih terpusat kepada proses pembelajaran. Dengan adanya metode ini, pemahaman siswa jadi lebih mendalam. Metode tanya jawab akan lebih efektif dalam mencapai tujuan apabila sebelum proses pembelajaran siswa ditugasi membaca materi yang akan dibahas.

\section{Metode Penelitian}

\subsection{Desain Penelitian}

Penelitian ini merupakan penelitian tindakan kelas (classroom action reseach). Peneliti mencoba menerapkan variasi model pembelajaran yang baru yaitu pada pembelajaran penerapan belajar kelompok dan tanya jawab. Dalam penelitian tindakan kelas ini terdiri atas rangkaian empat kegiatan yang dilakukan dalam siklus berulang. Empat kegiatan utama yang ada pada setiap siklus, yaitu : (1) Perencanaan (planning), yaitu persiapan yang untuk pelaksanaan PTK, (2) Tindakan (acting), yaitu deskripsi tindakan yang akan dilakukan, skenario tindakan, perbaikan dan prosedur tindakan yang diterapkan, (3) Observasi (observing), yaitu kegiatan mengamati dampak atas tindakan yang dilakukan, dan (4) Refleksi (reflecting), yaitu kegiatan evaluasi tentang perubahan yang terjadi atau hasil yang diperoleh atas data yang terhimpun sebagai bentuk dampak tindakan yang telah dirancang.

\subsection{Waktu dan Tempat Pelaksanaan}

Penelitian dilakukan di SMP PGRI Salawati Kabupaten Sorong. Penelitian ini dilaksanakan pada bulan Januari - Februari 2018.

\subsection{Subjek Penelitian}


Subjek Penelitian Tindakan Kelas ini adalah siswa kelas VII B SMP PGRI Salawati Kabupaten Sorong yang beragama Kristen sebanyak 10 siswa. Penelitian tindakan kelas data yang dikumpulkan dapat berbentuk kuantitatif maupun kualitatif.

\subsection{Teknik Pengumpulan Data}

Teknik yang dipergunakan untuk mengumpulkan data dalam penelitian ini adalah dengan teknik pengamatan (observasi) atau pengamatan secara langsung untuk mengamati tindakan dengan menggunakan metode belajar kelompok dan tanya jawab. Selanjutnya pada tiap siklus dilaksanakan tes untuk mengetahui hasil belajar siswa.

\subsection{Teknik Analisis Data}

Pada penelitian ini peneliti menggunakan teknik analisis deskriptif kualitatif, yaitu metode penelitian yang bersifat menggambarkan kenyataan atau fakta sesuai dengan data yang diperoleh dengan tujuan untuk mengetahui prestasi belajar yang dicapai siswa, juga untuk memperoleh respon siswa terhadap kegiatan pembelajaran serta aktivitas siswa selama proses permbelajaran. Hasil pengamatan untuk motivasi belajar dan hasil tes akan dibuat perhitungan sederhana rataan, prosentase, maksimum, minimum yang akan digunakan untuk mendiskripsikan hasil evaluasi.

\section{Hasil Penelitian Dan Pembahasan}

Berdasarkan pengamatan yang dilakukan oleh peneliti dari tindakan siklus I dan II diperoleh hasil sebagai berikut:

Tabel 1. Peningkatan Motivasi Belajar Siswa Siklus I

\begin{tabular}{cccccc}
\hline \multirow{2}{*}{$\begin{array}{c}\text { Skor } \\
\text { Motivasi }\end{array}$} & \multicolumn{4}{c}{ Siklus I } & \multirow{2}{*}{ Keterangan } \\
\cline { 2 - 4 } & F & $\%$ & F & $\%$ & \\
\hline $1-5$ & 3 & 30 & 2 & 20 & Kurang \\
$6-10$ & 5 & 50 & 4 & 40 & Cukup \\
$11-15$ & 2 & 20 & 4 & 40 & Baik \\
$16-20$ & 0 & 0 & 0 & 0 & Baik Sekali \\
JUMLAH & 10 & 100 & 10 & 100 & \\
\hline
\end{tabular}

Dari tabel di atas menunjukkan bahwa pada pertemuan pertama siklus I sebanyak 2 orang (20\%) siswa yang memiliki motivasi kurang, 5 orang (50\%) siswa yang tergolong memiliki motivasi cukup, 3 orang (30\%) yang tergolong memiliki motivasi baik dan tidak ada siswa yang tergolong memiliki motivasi baik sekali. Selanjutnya siswa dinyatakan telah termotivasi dalam belajar jika berada pada kriteria atau kategori cukup, baik dan baik sekali. 
Pada pertemuan kedua siklus I sebanyak 2 orang (20\%) siswa yang memiliki motivasi kurang, 4 orang (40\%) siswa yang tergolong memiliki motivasi cukup, 4 orang (40\%) yang tergolong memiliki motivasi baik, dan belum ada siswa yang tergolong memiliki motivasi baik sekali. Selanjutnya siswa dinyatakan telah termotivasi dalam belajar jika berada pada kriteria atau kategori cukup, baik dan baik sekali.

Berdasarkan hasil perhitungan dan kriteria motivasi belajar siswa secara klasikal diperoleh hanya 8 orang ( 4 orang tergolong motivasi cukup, 4 orang motivasi baik dan belum ada yang termotivasi sangat baik) atau $80 \%$ siswa yang telah termotivasi dalam belajar dan jumlah ini masih kurang dari $85 \%$ sehingga secara klasikal atau kelas siswa dinyatakan masih belum termotivasi dalam belajar.

Tabel 2. Peningkatan Motivasi Belajar Siswa Siklus II

\begin{tabular}{cccccc}
\hline \multirow{2}{*}{ Skor } & \multicolumn{4}{c}{ Siklus I } & \multirow{2}{*}{ Keterangan } \\
\cline { 2 - 4 } Motivasi & \multicolumn{2}{c}{ Pertemuan I } & \multicolumn{2}{c}{ Pertemuan II } & \\
\cline { 2 - 4 } & F & $\%$ & F & $\%$ & Kurang \\
\hline $1-5$ & 1 & 10 & 0 & 0 & Cukup \\
$6-10$ & 5 & 50 & 4 & 40 & Baik \\
$11-15$ & 2 & 20 & 4 & 40 & Baik Sekali \\
$16-20$ & 1 & 10 & 2 & 20 & \\
JUMLAH & 10 & 100 & 10 & 100 & \\
\hline
\end{tabular}

Berdasarkan hasil perhitungan dan kriteria motivasi belajar siswa secara klasikal diperoleh 9 orang (5 orang tergolong motivasi cukup, 3 orang motivasi baik dan 1 orang motivasi sangat baik) atau $90 \%$ siswa yang telah termotivasi dalam belajar dan jumlah ini sudah tergolong siswa termotivasi belajar karena sudah melebihi nilai $85 \%$ secara klasikal sehingga kelas siswa dinyatakan sudah termotivasi dalam belajar. Meskipun sudah termasuk dalam kriteria termotivasi, peneliti ingin melanjutkan penelitian ke pertemuan kedua untuk melihat peningkatan motivasi belajar dengan metode belajar kelompok dan tanya jawab.

Tabel di atas menunjukkan bahwa pada pertemuan kedua siklus II sebanyak tidak ada siswa yang memiliki motivasi kurang, 4 orang (40\%) siswa yang tergolong memiliki motivasi cukup, 4 orang (40\%) yang tergolong memiliki motivasi baik, dan 2 orang (20\%) yang tergolong memiliki motivasi baik sekali. Selanjutnya siswa dinyatakan telah termotivasi dalam belajar jika berada pada kriteria atau kategori cukup, baik dan baik sekali. Berdasarkan hasil perhitungan dan kriteria motivasi belajar siswa secara klasikal diperoleh 10 orang (4 orang tergolong motivasi cukup, 4 orang motivasi baik dan 2 orang motivasi sangat baik) atau $100 \%$ siswa yang telah termotivasi dalam belajar. 
Pada Tabel 1 dan 2 menunjukkan bahwa hampir semua pertemuan telah mengalami peningkatan. Proses pembelajaran dengan metode belajar kelompok dan tanya jawab apabila siswa tidak siap, maka siswa merasa takut, dan apabila pengajar kurang dapat mendorong siswa, maka siswa juga menjadi tidak berani untuk bertanya. Namun setelah dilakukan belajar kelompok selama beberapa pertemuan, siswa menjadi lebih aktif karena sudah mulai terbiasa dalam berdiskusi dan siswa senang belajar secara kelompok.

Peran guru sangat membantu dalam peningkatan motivasi belajar siswa. Siswa dapat belajar sendiri dengan kelompoknya dan berdiskusi mengenai soal yang diberikan.Siswa lebih aktif dengan belajar sendiri dan guru hanya memberi arahan dan bimbingan secara menarik. Oleh karena itu, dalam merancang suatu proses pembelajaran guru hendaknya mengetahui kemampuan dasar yang dimiliki siswa sehingga siswa dapat menerima manfaatnya.

Berdasarkan penjelasan di atas, dengan menggabungkan metode belajar kelompok dan tanya jawab dianggap cocok dalam mengembangkan motivasi siswa untuk belajar terutama mata pelajaran Pendidikan Agama Kristen. Menurut Hasibuan dan Moedjiono (2009) menyatakan bahwa metode belajar kelompok adalah salah satu strategi belajar mengajar yang memiliki kadar cara belajar siswa aktif. Maka dari itu, merupakan kegiatan yang melibatkan siswa secara berkelompok dalam proses pembelajaran sehingga siswa menjadi aktif dalam belajar. Sejalan dengan hal di atas. Menurut Aprilia (2008) metode tanya jawab bertujuan untuk menarik perhatian siswa agar lebih terpusat kepada proses pembelajaran. Dengan adanya metode ini, pemahaman siswa jadi lebih mendalam tentang mata pelajaran Pendidikan Agama Kristen (PAK).

\section{Simpulan dan Saran}

\subsection{Kesimpulan}

Berdasarkan hasil penelitian, analisis dan refleksi dari tiap-tiap siklus dikemukakan beberapa kesimpulan sebagai berikut:

1. Pada siklus I pertemuan kedua siswa belum dikatakan termotivasi secara klasikal. Namun terjadi peningkatan sebesar $80 \%$ siswa yang termotivasi dari sebelumnya $70 \%$ siswa yang termotivasi.

2. Setelah dilakukan perbaikan dalam kegiatan belajar mengajar pada siklus II, semua siswa sudah dikatakan termotivasi secara klasikal sebesar $100 \%$ pada pertemuan pertama dan kedua.

3. Upaya untuk meningkatkan hasil belajar siswa dapat dilakukan dengan penggabungan metode belajar kelompok dan tanya jawab.

\subsection{Saran}


Berdasarkan kesimpulan yang diperoleh maka peneliti mengajukan saran kepada siswa untuk selalu menumbuhkan motivasi belajar, berani bertanya dan mengemukakan pendapat dan mampu menyelesaikan tugas yang diberikan dan juga diharapkan guru memahami metode pengajaran yang efektif dan menyenangkan dalam meningkatkan motivasi belajar siswa. Penerapan metode belajar kelompok dan tanya jawab dapat digunakan dan dimodifikasi dalam proses belajar mengajar.

\section{Daftar Pustaka}

Aprilia, D. S. 2008. Keefektifan Metode Tanya Jawab Untuk Meningkatkan Proses Belajar Mengajar Dalam Bahasa China di Sma Kristen 1 Surakarta. Surakarta: Universitas Sebelas Maret

Kemendikbud (Kementerian Pendidikan dan Kebudayaan). 2013. Buku Guru Pendidikan Agama Kristen dan Budi Pekerti. Jakarta : Politeknik Negeri Media Kreatif.

Hasibuan, J. J. dan Moedjiono. 2009. Proses Belajar Mengajar. Bandung : PT. Remaja Rosdakarya. Supriadi, D. 1999. Mengangkat Citra dan Martabat Guru. Yogyakarta: Adicita Karya Nusa.

Yamin, M. 2007. Desain Pembelajaran Berbasis Tingkat Satuan Pendidikan. Jakarta: Gaung Persada Press 